\title{
Study on the socioeconomic characteristics influencing the involvement of Garo community on farm income and identifying the problems associated with it
}

\author{
Rahat Ahmed Juice \\ Lecturer, Department of Agricultural Economics, Bangladesh Agricultural University, Mymensingh-2202, Bangladesh \\ Email: juicesarker6@gmail.com \\ Dr. M. Saidur Rahman \\ Professor, Department of Agricultural Economics, Bangladesh Agricultural University, Mymensingh-2202, Bangladesh \\ Email: $\underline{\text { saidurbau@yahoo.com }}$
}

Md. Asraf Mahmud Hasif

Undergraduate Student, Faculty of Agricultural Economics and Rural Sociology, Bangladesh Agricultural University, Mymensingh2202, Bangladesh

Email: mdasrafmahmudhasif32@gmail.com

DOI: $10.31364 / \mathrm{SCIRJ} / \mathrm{v} 7.19 .2019 . P 0919694$

http://dx.doi.org/10.31364/SCIRJ/v7.i9.2019.P0919694

\begin{abstract}
The focus of the study was to address the socioeconomic characteristics influencing the involvement of Garo community on farm income and identifying the problems associated with it covering two upazillas namely Susong Durgapur and Purbadhola in Netrakona district. A total of 60 Garo households of farm activities practicing households were selected as sample following purposive random sampling technique. Primary data were collected during April 2017 to September 2017 through field survey method. Econometric analysis and Cobb-Douglas (log-log) regression model were employed to achieve the objectives. The major findings of the study were that most of the respondent's age was between 31-50 years. It was found that Garo ethnic culture was very rich in their own unique style. Languages, marriage system, dresses, ornaments, food and drink, social rituals, dance, musical instruments of Garo ethnic group are different from that of other religious communities. Agriculture is their main occupation. Secondary occupation namely small trader, carpenter, cottage industry, boutique shop, parlor, etc., were non-farm activities in the study areas. Their education level was comparatively lower. The main livelihood activities of Garos are agricultural practices in the plain land and in their homesteads. They used to grow rain fed crop e.g. Aman and Aus rice in the plain land. These are their main income sources. The explanatory variables were age of the household head, farm size of the household, experiences of farming, year of schooling of the household head, NGO involvement and credit facilities. Most of the variables in the model had significant impact on Garo household's income. The study also identified some problems faced by the farmers and probable solutions relating to those problems were also mentioned. Finally, some policy recommendations based on the findings of the study were suggested.
\end{abstract}

\section{Introduction}

The indigenous or tribal people of Bangladesh refer to native ethnic minorities in south-eastern, north-western, north-central and north-eastern regions of the country. These regions include the Chittagong Hill Tracts, Sylhet Division, Rajshahi Division and Mymensingh Division. The tribals are the aborigines of Bangladesh. The tribes are ethnically quite different from the local people. There are 27 tribal groups in Bangladesh (BBS 2010, 2015). The tribal people occupy a significant place in Bangladesh and have an important role in production activities to run their lives. Agriculture is now the only major means of living of this community (Ghosh, 2001). Tribal populations of Bangladesh are a purely agricultural people and depend entirely on their crops for subsistence. Most families cultivate vegetables in their homestead areas. Pig rearing is another popular practice among them. The majority of the tribal population lived in rural settings, where many practiced shifting cultivation.

This present study deals with the involvement of Garo community with farm-based income in Netrakona district. 'Garo's are mainly an indigenous group in Meghalaya, India and neighboring areas of Bangladesh. Mymensingh, Netrakona, Jamalpur, Sherpur and 
Sylhet are the main focused area where 'Garo'-ethnic people live. The Garo community in Bangladesh largely lives in Haluaghat, Dhobaura, Shusang Durgapur and Kolmakanda of Mymensingh and Netrakona districts.

Socioeconomic characteristics of the Garo households differ from one another in many aspects. The selected characteristics of present study are here age, education, occupational status and farm size towards their social status. Age of farmers have an influence on the production and in the better management of their life style. Young and middle age Garo farmers are large in number. Mainly these two categories people are involved in earning and all kinds of farm and non-farming activities. Older people mainly, older Garo women are involved in cottage industries. There have been taken many changes in recent decades till there exist a direct influence of the old farmers in life style and livelihoods in the Garo community. Education is an inevitable prime prerequisite for progress in any field. Education of farmers helps to increase productivity. Literate farmers can have better access to the relevant technical information for improvement of farm income. Agriculture is the main means of living of Garo people. Farm size of selected households was defined as the sum total of all types of land possessed by the Garo farmers and having legal land right on it. The ownership given by revenue rule, acquisition of land by the forest departments and forfeiting of land by the influential or political leaders, the sale out of land for family need and might other causes made the Garos to lose large forest or hilly land. The land ownership is still uncertain to some extent.

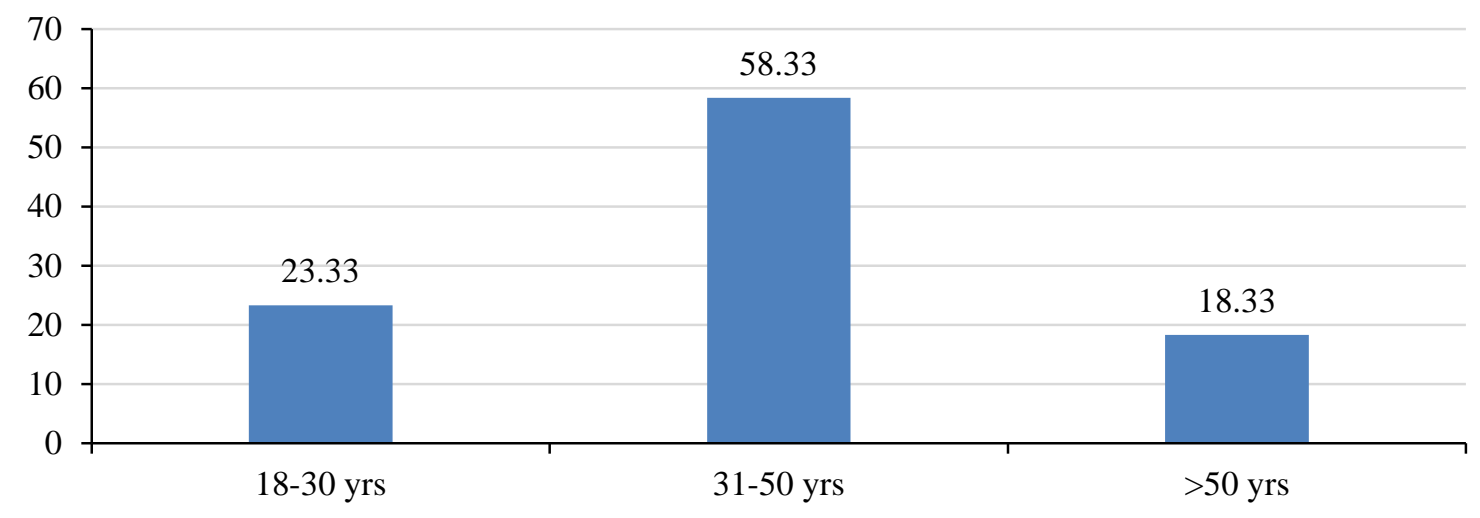

Figure 1: Age distribution of Garo people

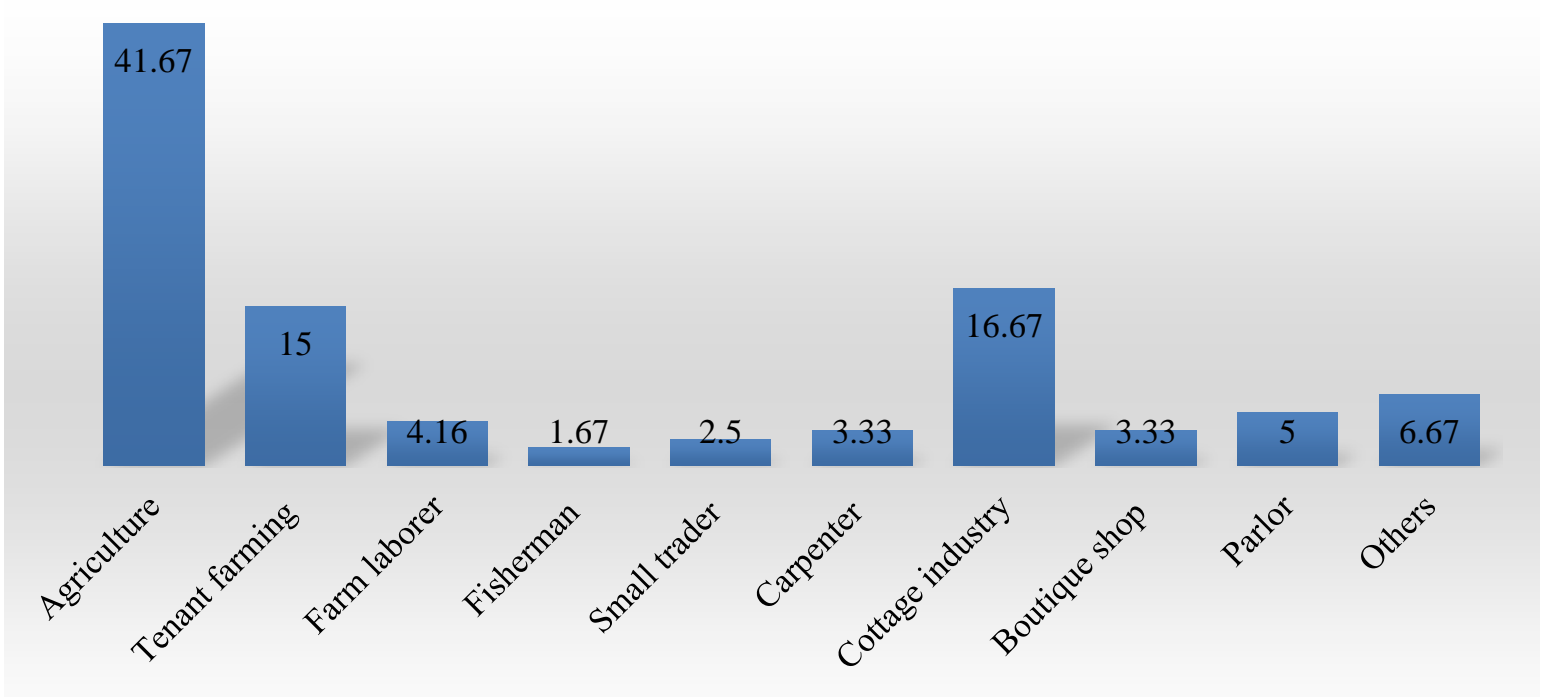

Figure 2: Occupational categories of the Garo households

The literature reviews in below indicate that most of the research studies dealt with either agricultural or livelihood aspects of tribal communities. Toppo et al. (2016) evaluated the socioeconomic condition of plain land tribal people in Bangladesh. Sarkar et al. 
(2015) identified the traditional agricultural tools used by tribal farmers in Eastern India. Ethnomed (2015) made an ethno-medicinal survey of various communities residing in Garo Hills of Durgapur, Bangladesh. Birthal et al. (2014) examined farm households' access to different income-generating activities, and their impact on income distribution in India. Munro and Parker (2014) conducted a study on an intersectionality analysis of gender, indigeneity, and food insecurity among ultra poor Garo women in Bangladesh. Barla (2013) carried out a study on the impact of new agricultural technology on tribal farming of Ranchi district in Jharkhand state of India. IAMR (2013) studied on rural non-farm employment in Gujarat, India. Anburaja and Nandagopalan (2012) aimed to study the agricultural activities of the Malayali Tribal for subsistence and economic needs. Alam (2012) conducted a study on indigenous people in greater Mymensingh area that was an economic study on Garo livelihood and food security. Ghosh (2009) carried out a study on tribal women's livelihood in forest-based industries in rural India. Naher (2009) conducted a study on socioeconomic situation of tribal people in some selected areas of Mymensingh district. Kumar (2006) reported that raising population pressure and urbanization, coupled with land degradation and global warming are causing food insufficiency in large parts of Asia. Uddin (2006) conducted a study on Traditional farming system of Garo tribe in Netrakona district. Gupta (2005) made an attempt to understand the complex relation of the socio-cultural life of Bangnijhumias of East Kameng to Jhum cultivation. Singh (2005) conduct a study on ethnic affairs. Partha (2003) conducted a study on bio-diversity of Madhupur tract that identified some problems of Garos in relation to agricultural production practices.

Almost 85 percent of Garo community people are involved in agricultural farming work. Their only means of living is farming. Though only a few numbers of people is involved in non-farming activities, but the number of this type of people is not very negligible. Majority of Garo had medium to high participation in agricultural activities. The state of Garo community is the worst in the country. This study area lags behind ecological degradation.

Some of the studies figured out the income and employment concerns, though these are not in the context of Bangladesh. The purpose of this study is to find out the current status of Garo community related to their income from agricultural sector and make some sustainable suggestions to improve their agricultural production practices through which they can make a better change in their livelihoods and socio-economic status. Appropriate strategies need to be formulated which can help the indigenous population to improve the socioeconomic status. They would be expected to provide some valuable information about indigenous people and to improve their livelihood. Very little or almost no study has been done with the interest of livelihood of indigenous people directly based on agricultural income Hence, the findings of this study would be helpful for policy makers so far.

\section{Objectives of the Study}

The specific objectives of this study were:

I. to examine the socioeconomic factors influencing for the involvement of Garo community on farm income;

II. to identify the problems and constraints of Garo community.

\section{Materials and Methods}

In rural areas and with people, it is difficult to conduct socio-investigation. The reliability of a scientific research depends to great extent on the appropriate methodology used in the researcher tries to follow a scientific and logical methodology for carrying out this research. A farm management study usually involves collection of information on individual farmers. For the study "farm survey"method was adopted for collecting data. Methods used for data collection was interviewing respondents, as the farmers of Bangladesh don't usually maintain records of their farm operations.

\section{Selection of the Study Site}

A farm management study requires the selection of an area where the particular purpose set for the study can be fulfilled. According to Yang (1965), "The area in which a business survey is to be carried out depends on the particular purposes of the survey and the possible cooperation from the farmers." The study area and sample units were selected keeping in mind the objectives of the study. Durgapur and Purbadhola of Netrakona district were purposively selected for the data collection.

\section{Sample Selection and Sampling Technique}

A sample of representative group is chosen in such a way that the information meets the purpose of the study. Then a sample of 60 farm activities performing Garo people were purposively chosen from the study area. 


\section{Data Collecting Instrument}

In a farm business survey, preparation of survey schedule needs considerable care and expertise. Preparation of the survey schedule is very important in any farm management survey. An interview schedule containing open and closed form of question originally written in English version was prepared to collect necessary and relevant information in accordance with the objectives of this study.

\section{Econometric analysis}

No single form of function can be used to characterize agricultural production under all environmental conditions. The algebraic form of the function and its magnitudes will vary with soil, climate, types and variety of crops, magnitude of other inputs in fixed quantity for the farm, etc. Hence a problem in each study is selection of an appropriate algebraic model, which is consistent with the phenomena under investigation. Here Cobb-Douglas type regression model (log-log model) was used to determine farm and non-farm income. The model has been selected using Davidson-Mackinnon test.

Theoretical model for Farm- income function was as follows:

$\ln Y_{i}=a+b_{1} \ln X_{1 i}+b_{2} \ln X_{2 i}+b_{3} \ln X_{3 i}+b_{4} \ln X_{4 i}+b_{5} \ln X_{5 i}+b_{6} \ln X_{6 i}+u_{i}$

Where,

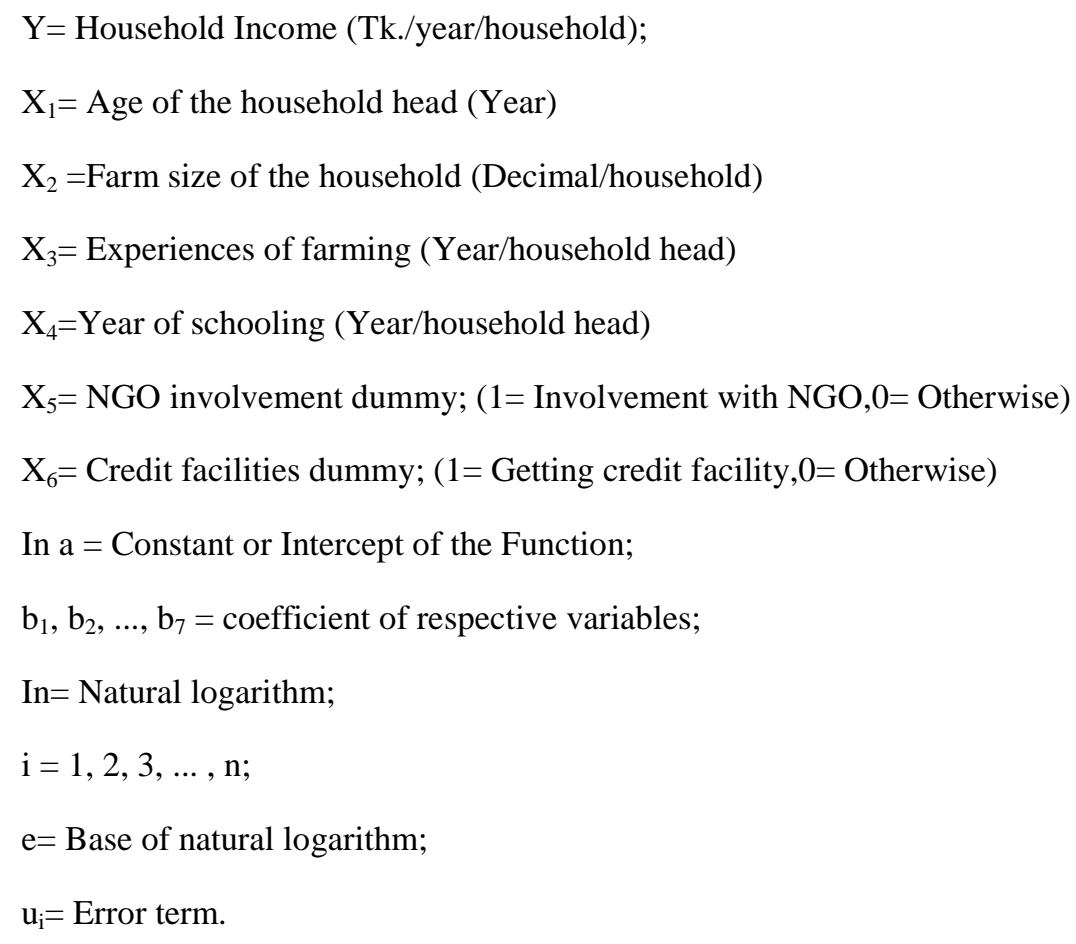

\section{Results and Discussion}

\section{Econometric Analysis}

Many factors might affect farm income of sampled household but it is quite difficult to include all the variables in a model due to theoretical and economic considerations. So, important variables were included to keep the model as simple as possible. Considering the effects of explanatory variables on farm income: Six explanatory variables namely: age of the household head $\left(\mathrm{X}_{1}\right)$,farm size of the household $\left(\mathrm{X}_{2}\right)$, experiences of farming $\left(\mathrm{X}_{3}\right)$, Year of schooling $\left(\mathrm{X}_{4}\right)$, NGO involvement $\left(\mathrm{X}_{5}\right)$, credit facilities $\left(\mathrm{X}_{6}\right)$.

As mentioned in the methodology chapter, the Cobb-Douglas type functional form tits best for this data set so C-D functional form has been used here. A special benefit of using C-D or log-log regression model was that the regression under OLS in logarithm, yields coefficients which represent partial elasticity's. The C-D type functional form broadly used by many researchers because it is simple to calculate and the elasticity's can directly be obtained from the coefficient. 
The results of the analysis are as follows:

Factors influencing farm income of sampled Garo households

\begin{tabular}{|c|c|c|c|c|}
\hline Factors & Coefficients & Std. Error & t-value & Significance \\
\hline Intercept & 9.07 & 0.33 & 27.00 & 1.18 \\
\hline $\begin{array}{l}\text { Age of the household head } \\
\text { (Year/household head) }\left(X_{1}\right)\end{array}$ & -0.076 & 0.092 & -0.83 & 0.41 \\
\hline $\begin{array}{lccc}\text { Farm } & \text { size } & \text { of } & \text { the } \\
\text { household(Decimal/household) }\left(\mathrm{X}_{2}\right) & \end{array}$ & $0.14 * * *$ & 0.036 & 3.82 & 0.000353 \\
\hline $\begin{array}{l}\text { Experiences of farming (Year/ household } \\
\text { head) }\left(\mathrm{X}_{3}\right)\end{array}$ & $0.065 * *$ & 0.029 & 2.17 & 0.034 \\
\hline $\begin{array}{l}\text { Year of schooling (Year/ household head) } \\
\left(\mathrm{X}_{4}\right)\end{array}$ & $0.062 * * *$ & 0.021 & 2.95 & 0.005 \\
\hline NGO involvement $\left(\mathrm{X}_{5}\right)$ & -0.00453 & 0.016 & -0.28 & 0.78 \\
\hline Credit facilities $\left(\mathrm{X}_{6}\right)$ & $0.045 * *$ & 0.019 & 2.31 & 0.000 \\
\hline $\mathrm{R}^{2}$ & \multicolumn{4}{|c|}{78.86} \\
\hline Adjusted $\mathrm{R}^{2}$ & \multicolumn{4}{|c|}{76.46} \\
\hline F- value & \multicolumn{4}{|c|}{32.95} \\
\hline
\end{tabular}

Source: Author's calculation based on field survey, 2017

Note:
*** Significant at 1 percent level of significance
** Significant at 5 percent level of significance
* Significant at 10 percent level of significance

\section{Age of the household head}

The age of the household head had a negative coefficient and it was 0.076, which was not significant and its meaning is other things remaining the same, one percent increase in the age of household head will decrease the household's farm income by 0.076 percent. This result was not expected because increase in the age of household heads could increase farm income. It was not happened may be because of some other factors. Farmers had to be more experienced and more efficient in farming activities to earn more income.

\section{Farm size}

The result showed that the farm size of the farmers had a positive coefficient and it was 0.14 with 1 percent level of significance. The meaning is, other things remaining the same, one percent increase in the farm size of household head will increase the household's farm income by 0.14 percent. This result indicated that increase in farm size would definitely increase the farm income of a household. 


\section{Experience on farming}

The experience on farming had a positive coefficient and it was 0.065 which was significant at 5 percent level of significance. The meaning is other things remaining the same, one percent increase in the experience on farming activities by the household head will increase the household's farm income by 0.065 percent. This result was expected because according to the results, farmers were more experienced and more efficient in practicing farming activities.

\section{Year of schooling of the household head}

The year of the schooling of the household head had a positive coefficient and it was 0.062 , which was significant at 1 percent level of significance. It means, other things remaining the same, one percent increase in the year of schooling of the household head will increase the household farm income by 0.062 percent. This result was expected because increase in the year of schooling of the household heads means farmers were more educated and more efficient in practicing farming activities.

\section{NGO involvement}

In this study, NGO involvement was a dummy variable. It had a negative effect. Thus as hypothesized, NGO's involvement would not increase the farm income. In the study area, when Garo farmers were in crisis period during production process, then they did not get any kind of sincere help from non-government organizations equally. There are various non-government organizations in the rural areas who work for the welfare of the farmers. But in the study area, NGOs were not involved in the welfare of the respondents. Their works and involvement were very limited among few people.

\section{Credit facility}

In this study, credit facility was a dummy variable. It had a positive effect. Thus as hypothesized, credit facility would have increased the farm income. This result was expected because if sampled households got credit facilities, their farm income would definitely be increased. During production activities, sometimes input price increased, that time respondents suffer from lack of financial support. Then they borrow money from plain land mahajans and sometimes some financial organizations provide them credit. Credit is not a production input but it can influence to increase production as well as farm income too.

\section{Multiple co-efficient of determination $R^{2}$}

The multiple co-efficient of determination $\left(\mathrm{R}^{2}\right)$ is a summary measure which tells how the sample regression line fits with data (Gujarati, 2003). The value of $\mathrm{R}^{2}$ was 0.7886 for all farm income group respondents. It means, the variables considered in the model can explain 78.86 percent variations of household's farm income for all farm income groups of the respondents.

\section{Adjusted $\mathbf{R}^{2}$}

The adjusted $\mathrm{R}^{2}$ was at 76.46 , it indicated that about 76.46 percent of the variation in the dependent variable was explained by the explanatory variables included in the model.

\section{Problems and constraints in the context of Garo society}

Garo people are facing different problems and constraints in farming. These problems have direct impact on the livelihood of this ethnic group. The problems were categorized into three groups: Technical problems, economical problems and social problems.

Problems and constraints in the context of Garo society presenting in a tabular form

\begin{tabular}{|c|c|c|}
\hline Problems and constraints & $\begin{array}{c}\text { No. of } \\
\text { respondent }\end{array}$ & Percentage \\
\hline \multicolumn{3}{|l|}{ Technical problems } \\
\hline i) Lack of education & 5 & 4.16 \\
\hline ii) Lack of scientific knowledge and technology & 2 & 1.67 \\
\hline
\end{tabular}




\begin{tabular}{|c|c|c|}
\hline iii) Lack of extension services & 5 & 4.16 \\
\hline iv) Lack of skill & 5 & 4.16 \\
\hline Attack of diseases and insecticides & 5 & 4.16 \\
\hline \multicolumn{3}{|l|}{ Economic problems } \\
\hline Lack of sufficient cultivable land for farming activities & 15 & 12.50 \\
\hline Lack of sufficient funding & 6 & 5.00 \\
\hline iii) Lack of good quality seed & 9 & 7.50 \\
\hline iv) High price of input & 6 & 5.00 \\
\hline v) Low price of output & 13 & 10.83 \\
\hline vi) Low yield of crops & 8 & 6.67 \\
\hline \multicolumn{3}{|l|}{ Social problems } \\
\hline Unemployment & 6 & 5.00 \\
\hline Lack of adoption of family planning by the people & 2 & 1.67 \\
\hline iii) Lack of medical treatment & 7 & 5.83 \\
\hline iv) Lack of awareness & 3 & 2.50 \\
\hline v) Electricity problem & 4 & 3.33 \\
\hline vi) Conflict with plain land dwellers & 8 & 6.67 \\
\hline vii) Natural calamities & 5 & 4.16 \\
\hline viii) Multiple ownership & 6 & 5.00 \\
\hline
\end{tabular}

Source: Field Survey, 2017

\section{Technical Problems}

Technical problems are related to lack of education lack of scientific knowledge and technology, lack of extension services, lack of sense, attack of diseases and insecticides, over flooding in rainy season, and insufficient water in dry season.

Education is the mandatory issue for a community's development. Education has direct impact on the livelihood of a community. In this study area, there was a noticeable lacking of educational facility. Some missionaries had impact on making educated the Garo community. But still lack of education was there a big problem. About 4.16 percent respondent of Garo community reported that lack of education was their technical problem.

In the study area, about 1.67 percent respondent households reported that they had lack of scientific knowledge and technology.

As ethnic groups are deprived from all kinds of facilities than plain land dwellers, so the ethnic groups need services from different organizations. In their production activities it was very necessary to get sufficient services from extension agencies. About 4.16 percent respondent farmers reported that they did not get any kind of services from extension agencies in the last couple of years. 
As Garo community was deprived from educational facilities and scientific knowledge and technology, their skill level was comparatively low. In the study area, about 4.16 percent respondent farmers were noticed that, they were suffering from lack of technical skill.

About 4.16 percent respondent farmers reported their crops and vegetables were attacked by diseases. Most of the respondent farmers use ethnic trap for pest management.

To overcome these problems, training program should be arranged to upgrade the knowledge on scientific techniques of production. Scientific use of chemicals should be ensured and supplementary supply of artificial irrigation should be arranged in the dry season.

\section{Economic Problems}

Economic problems related to farming activities were identified as lack of sufficient cultivable land for farming activities, lack of sufficient funding, lack of good quality seeds, high price of inputs, low price of output, and low yield of crops.

The Garo farmers face endless hindrances in crops, livestock, fisheries and forestry sectors from all corners. Lack of cultivable land is one of the major problems identified by the respondent households. Most of Garo respondents in the study area were suffering from lack of adequate cultivable land for farming activities. About 12.50 percent respondent reported that lack of sufficient cultivable land for production purpose was one of the major problems for them.

Most of farmers were not economically solvent to run the farm smoothly without any financial support from outside. In this case, they did not get loan from financial institution. They had to borrow money from local NGOs at higher interest rate for conducting farming activities. About 5 percent respondent reported that lack of sufficient funding is one of the obstacles in farming and non-farming activities in the study area.

In the study area, lack of quality seeds was one of the major problems for agricultural production practices. About 7.50 percent farmers complained about absence of quality seeds for production purpose.

About 5.00 percent farmers reported that high price of agricultural inputs was one of the important economic problems in the study area.

Low price of output was considered as another important problem reported by 10.83 percent respondent farmers. Most of the respondent farmers had to sell their products at local market with low prices. In addition that they face transportation problem at local level and its cost was high as well.

Low yield of crops like reported another economical problem in the study area. About 6.67 percent respondent farmers were complained that due to sufficient inputs and credit facilities, yield of crops was remaining low.

To overcome these problems, immediate measures should be taken; such as simplifications of lending procedures and group should be formed to buy and stock seeds, feed and fertilizers when these are available. The government organization should also take some measures for ensuring availability of inputs at reasonable prices at proper time.

\section{Social Problems}

In the study area, social problems were related to unemployment, lack of adoption of family planning by the people, lack of medical treatment, lack of awareness, electricity problem, lack of government support, corruption, conflict with plain land dwellers, natural calamities and multiple ownership.

Unemployment was one of the major social problems in Garo community. In the study area, about 5 percent respondent household complained that unemployment was the obstacles in their development.

This problem is comparatively lower in the study area. About 1.67 percent respondent reported that they did not take family planning policy.

In the study area, about 5.83 percent respondent reported that they were suffering from lack of medical treatment.

In the study area, about 2.5 percent respondent reported that they were suffering from lack of awareness about their present socioeconomic conditions.

www.scirj.org

(C) 2019, Scientific Research Journal

http://dx.doi.org/10.31364/SCIRJ/v7.i8.2019.P0819694 
In the study area, about 3.33 percent respondent farmers complained that they were suffering from electricity problem. This problem had a negative impact on the production activities.

Garo ethnic group is the most ancient ethnic group of our country. Normally they live here with peace and calm. But they always maintain a distance from the plain land dwellers. There is a silent confliction between ethnic group and plain land dwellers. In the study area, about 6.67 percent respondent reported that they had conflict with plain land dwellers.

Natural calamities keep direct impact on the production activities and livelihood of a community, particularly that community which is completely depended on nature, whose belief, culture, traditions all are depended on nature. In our study area, about 4.16 percent respondent reported that natural calamities had impact on their production as well as household income. These natural calamities are one of the social problems of this ethnic group.

In the study area, about 5 percent respondent households reported that multiple ownership of cultivable land was one of the important social problems among their community. Multiple-ownership was also a cause of yield decreasing and lower output.

\section{Conclusions and Policy Recommendation}

In this study, among 60 selected Garo samples, almost 62.5 percent samples are directly involved with agricultural farming activities. Results of empirical analysis for assessing Garo household's farm income reveal that among the six independent variables, nam ely age of the household head, farm size of the household, experiences of farming, years of schooling of the household head, NGO involvement and credit facilities. Four independent variables were found significant- they are: farm size of the households, experiences of farming, year of schooling of the household head and credit facilities. The value of adjusted $\mathrm{R}^{2}$ was 0.7646 in case of household farm income function. This indicates that 76.46 percent of the variations in the dependent variable explained by the explanatory variables included in the model. The measures of the overall significance of the estimated regression F-value was 32.95 implying that all the explanatory variables are important for explaining the variations of the dependent variable.

In the study area, there were some common problems reported by the respondent of Garo households. Some technical problems such as lack of education, lack of scientific knowledge and technology, lack of extension service, lack of skill, attack of diseases and insecticides were identified in the study area. The major economic problems faced by the Garo respondent were lack of sufficient cultivable land for farming activities, lack of sufficient funding, lack of good quality see, high price of input, low price of output and low yield of crops. There were numbers of social problems faced by the Garo respondent households. Some of those were unemployment, lack of adoption of family planning by the people, lack of medical treatment, lack of awareness, electricity problem, conflict with plain land dwellers, natural calamities and multiple-ownership. The present study also recommended some policy measures and probable solutions for recovering the constraints.

Some policy recommendations based on the findings and conclusions of the study area presented below:

i. Since agriculture is the main source of income for the respondent households so they should be encouraged to increase the involvement of farming activities for improving their livelihoods.

ii. Promotion of knowledge on the benefits of farming activities should be ensured through extension agents and local NGOs.

iii. They need good communication and market facilities for making more profit from their agricultural production.

iv. Adequate scientific knowledge and method should be provided to the respondents to increase their household income to improve their livelihood status more.

v. Respondents should be encouraged to attend training programs on the proper utilization of land for production purpose which will increase their farm income.

vi. Multiple ownership of land should be eradicated with the help of corresponding ministry and direct involvement of the government.

\section{References}

Anburaja V., Nandagopalan V. 2012. Agricultural Activities of the Malayali Tribal for Subsistence and Economic Needs in the Mid Elevation Forest of PachaMalai Hills, Eastern Ghats, Tamil Nadu, India. International Journal of Agricultural Research, Innovation and Technology.

Alam, A. K. M. A. 2012. A Study on Indigenous People in Greater Mymensingh: An Economic Study on Garo Livelihood and Food Security, M.S. (Ag.Econ.Ed.) thesis, Bangladesh Agricultural University, Mymensingh.

www.scirj.org

(C) 2019, Scientific Research Journal

http://dx.doi.org/10.31364/SCIRJ/v7.i8.2019.P0819694 
Arook Toppo, Md. R. Rahman, Md. Y. Ali, A. Javed 2016. Socio-economic condition of Plain Land Tribal People in Bangladesh, Social Sciences, Vol. 5, No. 4, 2016, pp. 58-63.

BBS 2015.Statistical Year Book of Bangladesh, Bangladesh Bureau of Statistics, Ministry of Planning, Government of People's Republic of Bangladesh, Dhaka.

BBS 2010. Statistical Year Book of Bangladesh, Bangladesh Bureau of Statistics, Ministry of Planning, Government of People's Republic of Bangladesh, Dhaka.

Barla, M. 2013. The Impact of New Agricultural Technology on Tribal Farming: A Study of Ranchi District of Jharkhand State, Journal of Economic and Social Development.

Birthal S. P., Digvijay S. N, Awadesh K. J., and Dhiraj S. 2014. Income Sources of Farm Households in India: Determinants, Distribution Consequences and Policy Implication, Agricultural Economics Research Review, Vol. 27, No. 1, 2014, PP. 3748.

Ethnomed, J. E. 2015. Ethnomedicinal Survey of Various Communities Residing in Garo Hills of Durgapur, Bangladesh.

Ghosh 2001. "Perceptual understanding of environment with linkage in economic discernment on two tribal community of West Bengal". A Journal of the Anthropological Survey of India.

Gujarati, D. N. 2003. Basic Econometrics, $3^{\text {rd }}$ edn. McGraw Hill Book Company, Inc. New York.

Ghosh, N. 2009. In Search of a Canopy: Tribal Women's Livelihood in Forest-based Industries in Rural India.

Gupta, V. 2005. Jhum Cultivation Practices of the Bangnis (Nishis) of Arunachal Pradesh, IJTk, Vol. 4, No. 1, 2005, PP. 47-56.

IAMR 2013. Rural Non-Farm Employment: A Study in Gujrat, Institute of Applied Manpower Research, Planning Commission, Government of India, IAMR Report No. 4.

Kumar, B. M. 2006. Agro forestry: The New Old Paradigm for Asian Food Security, Journal of Tropical Agriculture, Vol. 44, No. 114, January, 2006.

Munro Jenny, B. Parker 2014. An Intersectionality Analysis of Gender, Indigeneity, and Food Insecurity among Ultra Poor Garo Women in Bangladesh, International Journal of Indigenous Health, Vol. 10, Issue 1, 2014.

Naher, S. 2009. A Socioeconomic Study of Tribal People in Some Selected Areas of Mymensingh District, MS(in Ag.Econ) thesis, Bangladesh Agricultural University, Mymensingh

Partha, S. 2003.Biodiversity of Madhupur Tract. Bangladesh Resource Center for Indigenous Knowledge (BARCIK), Dhaka.

Sarker B., P. Kumar, A. Dey, Ujjwal K., Kamal S., and B. P. Bhatt 2015. Traditional Agricultural Tools Used by Tribal Farmers in Eastern India, Research Journal of Agricultural Sciences, Vol. 6, No. 1, pp. 215-219.

Singh L. 2005. Ethnic Community Development Organizations: Journal of Ethnic Affairs, Vol. 1, August, 2005.

Uddin, M. S., R. Ahmed, M. F.K. Khan, M. A. S. A. Khan, M. S. Rahman 2006. Traditional Farming System of Garo Tribe in Netrokona District of Bangladesh, Department of Forestry, Shahjalal University of Science and Technology, Sylhet, Bangladesh, Department of Agroforestry, Hajee Mohammad Danesh Science and Technology University, Dinajpur, Bangladesh.

Yang, W.Y.1965. Methods of farm management investigation for improving farm productivity. Food and agricultural organizations of the united nations, rome, italy. 